\title{
Amorphus coralli gen. nov., sp. nov., a marine bacterium isolated from coral mucus, belonging to the order Rhizobiales
}

\author{
Dafna Zeevi Ben Yosef, Eitan Ben-Dov and Ariel Kushmaro
}

Correspondence

Ariel Kushmaro

arielkus@bgu.ac.il

\author{
Department of Biotechnology Engineering and National Institute for Biotechnology, Ben-Gurion \\ University of the Negev, PO Box 653, Beer-Sheva 84105, Israel
}

The order Rhizobiales, the nomenclature of which was suggested in the most recent edition of Bergey's Manual of Systematic Bacteriology, is the biggest group within subgroup 2 of the Alphaproteobacteria (Garrity \& Holt, 2001). According to Bergey's Manual (Garrity \& Holt, 2001), the Alphaproteobacteria are divided into six orders. The order Rhizobiales is divided into ten families, based on $16 \mathrm{~S}$ rRNA gene phylogenetic analyses (Garrity \& Holt, 2001). Among the six orders of the Alphaproteobacteria, marine bacteria are mainly distributed in three orders: 'Rhodobacterales', 'Sphingomonadales' and Caulobacterales (Jannasch \& Jones, 1960; Shiba et al., 1991; Giovannoni \& Rappé, 2000). Only a few members of the order Rhizobiales, such as the genus Rhodobium, including Rhodobium orientis and Rhodobium marinum (Hiraishi et al., 1995), and the genera Roseibium (Suzuki et al., 2000) and Aurantimonas (Denner et al., 2003), have been isolated from marine environments (Cho \& Giovannoni, 2003).

Coral reefs are the most diverse of all marine ecosystems, although most of this diversity remains uncharacterized. Recently, culture-independent techniques have revolutionized our knowledge of planktonic marine bacteria (reviewed by Giovannoni \& Rappé, 2000), although they have not been employed systematically to study bacteria living on coral reefs (Rohwer et al., 2001; Frias-Lopez et al., 2002). Corals that make up the backbone of these reefs harbour a diverse array of bacterial associates (reviewed by Brown \& Bythell, 2005). To date, very little is known of the

The GenBank/EMBL/DDBJ accession number for the 16S rRNA gene sequence of strain RS.Sph.026 ${ }^{\top}$ is DQ097300. metabolic capabilities of these bacteria, their function on the coral surface and their potential benefit to the coral host or symbiotic algae.

Strain RS.Sph. $026^{\mathrm{T}}$ was isolated from the mucus of the coral Fungia granulosa using the double encapsulation method developed by A. Kushmaro (unpublished results.) This bacterium exhibited the closest 16S rRNA gene similarity $(92 \%)$ to the marine, budding, phototrophic bacterium Rbi. orientis (Hiraishi et al., 1995). In this paper, we have compared the phenotypic, genotypic and phylogenetic characteristics of strain RS.Sph. $026^{\mathrm{T}}$ with those of Rbi. orientis (GenBank no. D30792).

Samples of mucus from healthy corals of $F$. granulosa were collected from the Red Sea (Gulf of Eilat), from depths of $10-15 \mathrm{~m}$, in front of the Inter-University Institute for Marine Science, Eilat, Israel $\left(29^{\circ} 51^{\prime} \mathrm{N} 34^{\circ} 94^{\prime} \quad\right.$ E). Bacteriological peel loops were used to collect the coral surface microlayer in situ and inserted into air-dry, sterile, $50 \mathrm{ml}$ polypropylene centrifuge tubes, sealed underwater. The tubes were brought to the surface and immediately placed on ice. Initial cultures of strain RS.Sph. $026^{\mathrm{T}}$ were obtained by using the recently developed agar sphere culturing technique, described by Kushmaro and others (unpublished results) and in patent application nos WO 2004/022698 A2 and EP1556480. This novel encapsulation technology for the isolation and culture of previously 'uncultivable' micro-organisms includes the collection of an environmental sample, estimation of the bacterial number and dilution of the sample in order to entrap approximately one bacterium in one agar sphere (1-2 mm 
in diameter). The diluted samples were mixed with warm autoclaved agar and a sphere was made by dripping agar droplets into cold mineral oil. The sphere size can be modulated by the nozzle diameter and drip rate. Coating of the agar spheres with a polymeric membrane was carried out by inserting them into a polymer solution (polysulfone) followed by transfer into a polymerization medium. The polymeric membrane coating allows an exchange of chemicals between the sphere and the environment, but restricts the movement of cells and enables their incubation in the environment (Kushmaro and others, unpublished results). Domestication of the novel bacterial strain, RS.Sph. $026^{\mathrm{T}}$, was achieved by repeated transfers through agar spheres and subsequent plating on $100 \%$ marine agar 2216 (MA-100\%; HiMedia Laboratories) enrichment plates.

Liquid cultures of strain RS.Sph. $026^{\mathrm{T}}$ in Leibovitz L-15 medium, supplemented with $3 \%$ heat-inactivated fetal calf serum (medium and supplements purchased from Biological Industries, Israel), were spread and purified as single colonies on MA- $100 \%$ and incubated at $22{ }^{\circ} \mathrm{C}$. The strains were maintained as viable cultures on MA-100\% agar plates at $4{ }^{\circ} \mathrm{C}$ and were also stored as $25 \%(\mathrm{v} / \mathrm{v})$ glycerol suspensions at $-80{ }^{\circ} \mathrm{C}$.

Strain RS.Sph. $026^{\mathrm{T}}$ was a Gram-negative, budding bacterium with a variety of amorphous morphologies, with cells ranging in size from 0.5 to $3 \mu \mathrm{m}$ (Fig. 1a). Strain RS.Sph. $026^{\mathrm{T}}$ differed from Rbi. orientis and Rbi. marinum

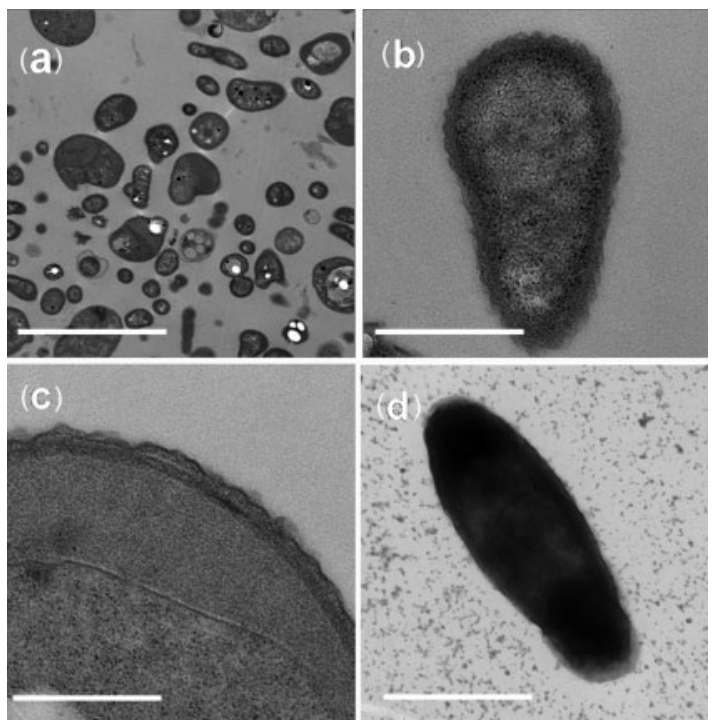

Fig. 1. Transmission electron micrographs of cells of strain RS.Sph.026 ${ }^{\top}$ 'domesticated' on marine agar. (a) Amorphous shapes, (b) cell arrangement and (c) lamellar arrangement of the intracytoplasmatic membrane. (d) Negatively stained cell showing no flagella. Bars, $5000 \mathrm{~nm}$ (a), $500 \mathrm{~nm}$ (b) and (c) and 1000 nm (d). in the following phenotypic characteristics: cell shape, cell diameter, rosette formation, motility and salinity requirement (see Table 1). All of these differences may be the result of the unique habitat of this bacterium. Living corals are often described as being slick with mucous secretions. Secreted mucus, whether still closely associated with the surface of a coral, or not, invariably becomes enriched with microbes, in comparison with the overlying water column (Coffroth, 1990). There is mounting evidence that the bacterial community that develops on the surface of the coral is distinctly different from that of the water column overlying it (Cooney et al., 2002; Frias-Lopez et al., 2002). In addition, as the mucus environment differs in viscosity (Brown \& Bythell, 2005) from the surrounding water environment, it is possible that these differences dictate the observed differences in morphology. Moreover, it should be mentioned that the amorphous cell shapes we observed could be cells that are unable to divide normally because of

Table 1. Differential characteristics of strain RS.Sph. $026^{\top}$ (Amorphus coralli gen. nov., sp. nov.) and recognized species of the genus Rhodobium

Taxa: 1, strain RS.Sph.026 ${ }^{\mathrm{T}}$; 2, Rbi. orientis (data from Hiraishi et al., 1995); 3, Rbi. marinum (Hiraishi et al., 1995). +, Positive (in most strains); - , negative (in most strains); $+/-$, variable (in different strains); (+), weak; ND, not determined. All taxa show the same internal membrane system and all are positive for oxidation of succinic acid, glucose and sorbitol and negative for oxidation of capric acid.

\begin{tabular}{|c|c|c|c|}
\hline Characteristic & 1 & 2 & 3 \\
\hline Cell shape & Amorphous & Rod & Rod \\
\hline Cell diameter $(\mu \mathrm{m})$ & $0.5-3$ & $0.7-0.9$ & $0.7-0.9$ \\
\hline Rosette formation & - & $+1-$ & - \\
\hline Motility & - & + & + \\
\hline Colour of cultures & $\begin{array}{l}\text { Cream (in } \\
\text { aggregates) }\end{array}$ & $\begin{array}{l}\text { Pink to } \\
\text { red }\end{array}$ & $\begin{array}{l}\text { Pink to } \\
\text { red }\end{array}$ \\
\hline Bacteriochlorophyll & ND & $a$ & $a$ \\
\hline Salt requirement & $0-4 \%$ & $4-5 \%$ & $1-5 \%$ \\
\hline Optimal pH & $7.5-8$ & $7.0-7.5$ & $6.9-7.1$ \\
\hline $\begin{array}{l}\text { Optimal temperature } \\
\left({ }^{\circ} \mathrm{C}\right)\end{array}$ & $25-30$ & $30-35$ & $25-30$ \\
\hline Aerobic dark growth & + & + & $(+)$ \\
\hline Denitrification & - & + & - \\
\hline $\begin{array}{l}\text { Fermentation of } \\
\text { fructose }\end{array}$ & - & - & + \\
\hline \multicolumn{4}{|l|}{ Oxidation of: } \\
\hline Citrate & $(+)$ & - & $+1-$ \\
\hline Acetic acid & - & + & + \\
\hline D-Fructose & - & + & + \\
\hline Glycerol & - & - & $+1-$ \\
\hline Lactose & - & + & $+1-$ \\
\hline Maltose & + & $\mathrm{ND}$ & $\mathrm{ND}$ \\
\hline Mannitol & + & $+1-$ & + \\
\hline Mannose & + & $\mathrm{ND}$ & ND \\
\hline Sorbitol & + & + & + \\
\hline
\end{tabular}


the lack of essential elements in the growth medium used (MA-100\%). Such abnormal dividing cells have been demonstrated with Escherichia coli that were thymine limited (Zaritsky et al., 1999; Zaritsky \& Woldringh, 2003).

Strain RS.Sph. $026^{\mathrm{T}}$ grew slowly and formed aggregates in liquid culture. On plates of MA-100\%, colonies could be detected only at 3 days after plating; hence the generation time was approximately $4-6 \mathrm{~h}$. Colonies on MA- $100 \%$ were cream in colour, convex, round and glossy and 0.5$1 \mathrm{~mm}$ in diameter. No photosynthetic or carotenoid pigments were detected in cells extracted from cultures grown on MA-100\% using a methanol/acetone mixture $(1: 1, \mathrm{v} / \mathrm{v})$ and a scanning UV/visible spectrophotometer (Biospec-1601; Shimadzu). No differences in growth were detected between light and dark conditions. This heterotrophic characteristic differentiates strain RS.Sph. $026^{\mathrm{T}}$ from its closest relatives Rbi. orientis and Rbi. marinum (see Table 1), which are able to grow anaerobically by photosynthesis and contain bacteriochlorophyll $a$ and carotenoids (Hiraishi et al., 1995). In spite of the lack of pigment, strain RS.Sph. $026^{\mathrm{T}}$ possessed a lamellar arrangement of the intracytoplasmatic membrane (Fig. 1b, c), a trait that resembles the lamellar arrangement of the closest related species, Rbi. orientis (Hiraishi et al., 1995). The detection of a lamellar membrane in strain RS.Sph.026 might imply that this bacterium had 'lost' its photosynthetic pigments due to the fact that its habitat is coral mucus, which is a rich environment that includes dissolved organic matter and sugars (see the review by Brown \& Bythell, 2005).

Biochemical tests were carried out by using API 20NE strips (micromethod for the identification of Gramnegative rods; bioMérieux) following the manufacturer's instructions. Carbon oxidation was analysed using Biolog GN microwell plates. Pure cultures (4-6 colonies) from MA- $100 \%$ plates were suspended in $20 \mathrm{ml}$ of the Biolog medium supplied (salinity of the medium was not adjusted due to the fact that this bacterium could grow in $0-4 \%$ $\mathrm{NaCl}$; see results below). The suspension was then distributed into Biolog GN plates containing 96 microwells, with a different carbon source in each and tetrazolium violet as an indicator of metabolic activity. The plates were incubated for $48 \mathrm{~h}$ at $30{ }^{\circ} \mathrm{C}$. Wells that showed a change of colour to purple were marked as positive for metabolic activity.

The results of the Biolog and API 20NE tests for carbon source utilization shown in Table 1 showed that strain RS.Sph $026^{\mathrm{T}}$ can metabolize the following sugars: arabinose, glucose, maltose, mannitol, mannose and sorbitol. Some of these sugars are found in abundance in coral mucus (see Meikle et al., 1987; Brown \& Bythell, 2005). Strain RS.Sph. $026^{\mathrm{T}}$ did not utilize fructose, lactose or acetic acid, substances that are utilized by Rbi. orientis and Rbi. marinum (see Table 1). Strain RS.Sph.026 ${ }^{\mathrm{T}}$ also utilized succinic acid, butyric acid, xylitol, Tween 40, putrescine, propionic acid, phenylalanine, ornithine, histidine and butanediol.
For electron microscopy, purified colonies from MA-100 \% agar were fixed with $3 \%$ glutaraldehyde in cacodylate buffer, then washed and gently mixed with $3 \%$ bacteriological agar, treated with osmium, dehydrated, embedded in Araldite epoxy resin and sectioned at $70-80 \mathrm{~nm}$. The resulting sections were stained with uranyl acetate and lead citrate and examined by using a JEM-1230 transmission electron microscope at $80 \mathrm{kV}$ excitation voltage. Negative staining was performed on exponentially growing cells that were centrifuged, washed twice with $1 \% \mathrm{PBS}$ at $\mathrm{pH} 8$ and placed in $1.5 \%$ glutaraldehyde. The cells were stained with $1 \%$ uranyl acetate and examined by using a JEM-1230 transmission electron microscope at $80 \mathrm{kV}$ excitation voltage. No flagella were detected on negatively stained cells (Fig. 1d). The temperature range for growth, tested at $4-37{ }^{\circ} \mathrm{C}$ on MA- $100 \%$, was $22-37{ }^{\circ} \mathrm{C}$ (optimum, 25$\left.30{ }^{\circ} \mathrm{C}\right)$. The $\mathrm{pH}$ range for growth examined at $\mathrm{pH} 4.0-10.0$ at the optimum growth temperature $\left(25-30{ }^{\circ} \mathrm{C}\right)$ on MA$100 \%$ agar plates was 6-10 (optimum, 7.5-8). The salinity range and optimum salinity for growth determined using a sea-salt mixture (Instant Ocean) for preparing artificial seawater at concentrations of $0-14 \%(\mathrm{w} / \mathrm{v})$ was $0-4 \%$, with no growth occurring on media containing $5 \%$ sea-salt mixture (optimum 3-4\%). The strain did not grow after incubation for 2 weeks on MA-100\% in an anaerobic cell (BD Gas Pak EZ).

For analysis of the cellular fatty acids, cells were grown on MA- $100 \%$ for 7 days and then transferred to tryptic soy agar at $28{ }^{\circ} \mathrm{C}$ before extraction of the fatty acids. The microbial fatty acid profile was analysed using the MIDI/ Hewlett Packard microbial identification system (Analytical Services), which uses GC profiles of fatty acid methyl esters. In total, seven kinds of fatty acids, containing 18-20 carbon atoms, were observed (Table 2). The measurable fatty acids were as follows: $\mathrm{C}_{18: 1} \omega 7 c, \mathrm{C}_{18: 0}, \mathrm{C}_{19: 0}$ cyclo $\omega 8 c, \mathrm{C}_{20: 1} \omega 7 c$, 11-methyl $\mathrm{C}_{18: 1} \omega 7 c, \mathrm{C}_{16: 0}$ and $\mathrm{C}_{18: 0} 3-\mathrm{OH}$. The most abundant fatty acid was cis-7-octadecenoic acid $\left(\mathrm{C}_{18: 1} \omega 7 c\right.$, $57.2 \%)$. The major fatty acid is similar to that found in $R b i$. marinum (Hiraishi et al., 1995), but four other abundant fatty acids, $\mathrm{C}_{19: 0}$ cyclo $\omega 8 c, \mathrm{C}_{20: 1} \omega 7 c$, 11-methyl $\mathrm{C}_{18: 1} \omega 7 c$ and $\mathrm{C}_{18: 0} 3-\mathrm{OH}$ are not present in Rbi. marinum (Table 2; Hiraishi et al., 1995).

Table 2. Fatty acid profiles of strain RS.Sph. $026^{\top}$ (Amorphus coralli gen. nov., sp. nov.) and Rbi. marinum

Values are percentages of the total fatty acids. ND, Not detected.

\begin{tabular}{|lcc|}
\hline Fatty acid & Strain RS.Sph.026 & Rbi. marinum \\
\hline $\mathrm{C}_{18: 1} \omega 7 c$ & 57.2 & 69 \\
$\mathrm{C}_{18: 0}$ & 6.5 & 14.1 \\
$\mathrm{C}_{19: 0}$ cyclo $\omega 8 c$ & 15.5 & $\mathrm{ND}$ \\
$\mathrm{C}_{20: 1} \omega 7 c$ & 11 & $\mathrm{ND}$ \\
$11-$ methyl $\mathrm{C}_{18: 1} \omega 7 c$ & 8.5 & $\mathrm{ND}$ \\
$\mathrm{C}_{16: 0}$ & 0.63 & 1.9 \\
$\mathrm{C}_{18: 0} 3-\mathrm{OH}$ & 0.79 & $\mathrm{ND}$ \\
\hline
\end{tabular}


Genomic DNA was extracted using a PowerSoil purification kit (Mo Bio Laboratories), according to the manufacturer's instructions. Genomic DNA was eluted by using $20-40 \mu \mathrm{l}$ of elution buffer or double distilled water and stored at $-20{ }^{\circ} \mathrm{C}$. Total DNA was amplified with a Mastercycler gradient thermocycler (Eppendorf) by PCR using $16 \mathrm{~S}$ rRNA primers for bacteria [forward primer, $\quad 8 \mathrm{~F} \quad\left(5^{\prime}\right.$-GGATCCAGACTTTGAT $(\mathrm{C} / \mathrm{T})(\mathrm{A} /$ C)TGGCTCAG-3') and reverse primer, 1512R (5'-GTGAAGCTTACGG(C/T)TAGCTTGTTACGACTT-3'), taken and modified (8F primer was shortened from $5^{\prime}$-end) according to Felske et al. (1997). The resulting 16S rRNA gene sequences were compared with those in the GenBank database using the basic local alignment search tool BLAST network service (http://www.ncbi.nlm.nih.gov/ blast/blast.cgi) and were aligned with sequences of representative species from the order Rhizobiales using CLUSTAL $\mathrm{W}$ with the MEGA package (Kumar et al., 2004). The phylogenetic tree (Fig. 2) was constructed by using the neighbour-joining method (Saitou \& Nei, 1987) with the MEGA package (Kumar et al., 2004). Bootstrap resampling analysis (Felsenstein, 1985) for 100 replicates was performed to estimate the confidence levels of the tree topologies.

The 16S rRNA gene sequence of strain RS.Sph. $026^{\mathrm{T}}$ (1438 bases) demonstrated a $92 \%$ similarity to the sequence of Rbi. orientis (D30792), a marine, budding, phototrophic bacterium (Hiraishi et al., 1995). In the phylogenetic tree, strain RS.Sph. $026^{\mathrm{T}}$ clustered within members of the order Rhizobiales, but had the highest similarity of only $92 \%$ to Rbi. orientis, Rhodobium gokarnense (Srinivas et al., 2007) and Rhodobium pfennigi (Caumette et al., 2007; not included in phylogenetic tree due to the short sequence). Furthermore, the relationship of strain RS.Sph. $026^{\mathrm{T}}$ to the genus Rhodobium is represented by the relatively low level $(60 \%)$ of bootstrap confidence that supported this node (see Fig. 2). For the determination of the DNA G+C content, the genomic DNA of strain RS.Sph.026 ${ }^{\mathrm{T}}$ was prepared according to a modified version of the procedure of Wilson (1987). The G+C content of the DNA was determined in three independent analyses using the HPLC technique (Mesbah et al., 1989) and was performed at the BCCM/LMG. The DNA G+C content of strain

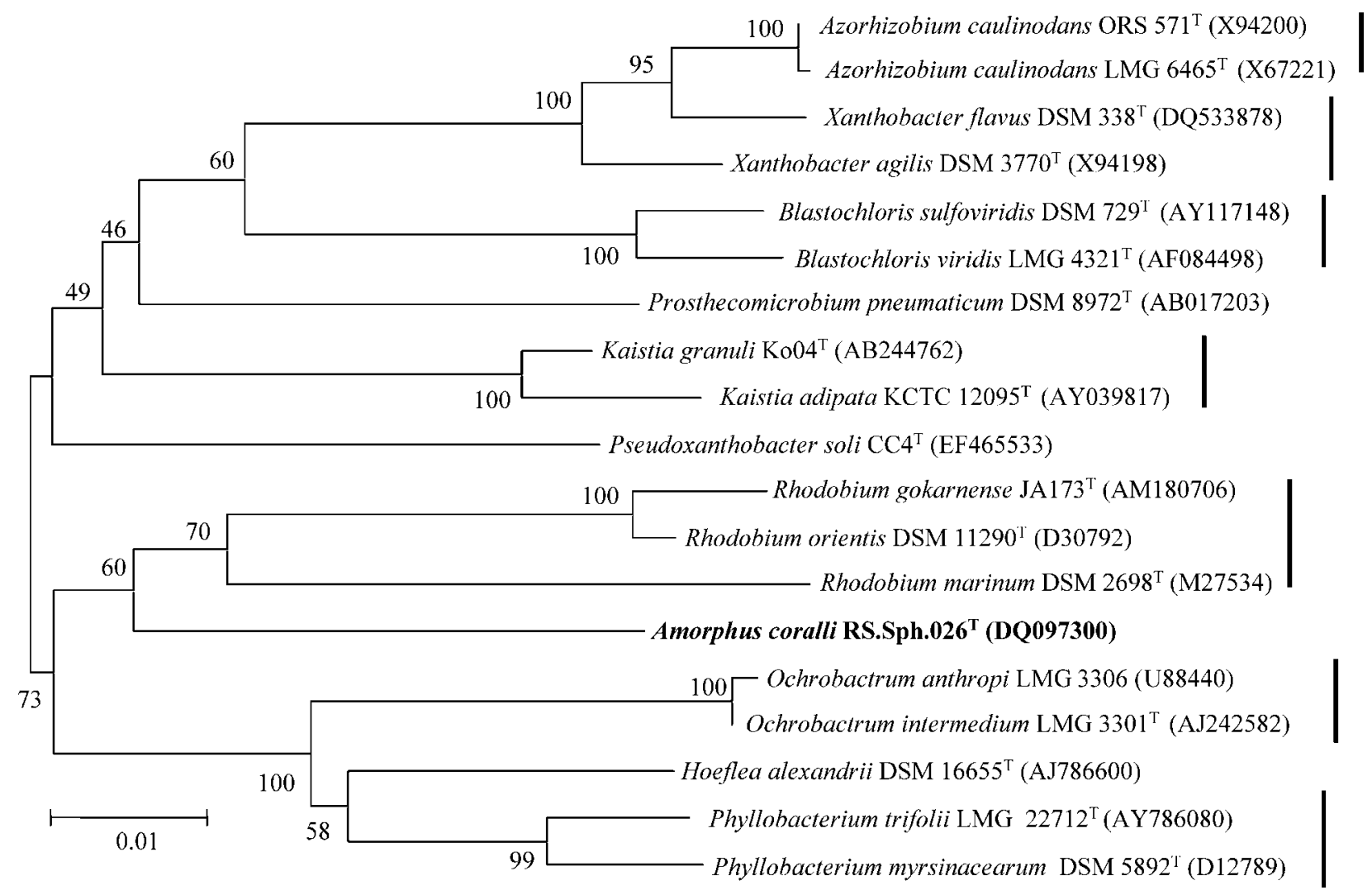

Fig. 2. Neighbour-joining phylogenetic tree based on $16 \mathrm{~S}$ rRNA gene sequences showing the relationships between strain RS.Sph. $026^{\top}$ and 18 representative species from the order Rhizobiales. Bootstrap percentages based on 100 replications are given at branch points. GenBank numbers are given in parentheses. Vertical lines indicate the genera. Bar, 0.01 substitutions per nucleotide position. 
RS.Sph. $026^{\mathrm{T}}$ was found to be $67.1 \mathrm{~mol} \%$. Based on the phenotypic characterization and the phylogenetic analysis, strain RS.Sph.026 ${ }^{\mathrm{T}}$ should be classified as representing a novel genus and species of the order Rhizobiales, for which the name Amorphus coralli gen. nov., sp. nov. is proposed.

\section{Description of Amorphus gen. nov.}

Amorphus [A.mor'phus. N.L. masc. n. Amorphus (from Gr. adj. amorphos without form, shapeless), a bacterium without defined shape].

Gram-negative, heterotrophic, non-motile, budding bacteria with morphologically different shaped structures of $0.5-3 \mu \mathrm{m}$. Cells have lamellar arrangements of the intracytoplasmatic membranes, but no photosynthetic pigments. Fermentative growth and denitrification do not occur. The type species is Amorphus coralli.

\section{Description of Amorphus coralli sp. nov.}

Amorphus coralli (co.ral'li. L. gen. n. coralli of coral, from which the organism was isolated).

Exhibits the following properties in addition to those given in the genus description. Optimal growth occurs at 25$30{ }^{\circ} \mathrm{C}, \mathrm{pH} 7.5-8$ and in $\mathrm{NaCl}$ concentrations of $3-4 \%$. The following carbon sources are utilized: glucose, arabinose, mannose, maltose, mannitol, mannose, sorbitol, succinic acid, butyric acid, xylitol, Tween 40 , putrescine, propionic acid, phenylalanine, ornithine, histidine and butanediol. Fatty acids are $\mathrm{C}_{18: 1} \omega 7 c, \mathrm{C}_{18: 0}, \mathrm{C}_{19: 0}$ cyclo $\omega 8 c, \mathrm{C}_{20: 1} \omega 7 c$, 11-methyl $\mathrm{C}_{18: 1} \omega 7 c, \mathrm{C}_{16: 0}$ and $\mathrm{C}_{18: 0} 3-\mathrm{OH}$. The $\mathrm{G}+\mathrm{C}$ content of the DNA of the type strain is $67.1 \mathrm{~mol} \%\left(T_{\mathrm{m}}\right)$.

The type strain, RS.Sph. $026^{\mathrm{T}} \quad\left(=\mathrm{LMG} \quad 24307^{\mathrm{T}}=\mathrm{DSM}\right.$ $19760^{\mathrm{T}}$ ), was isolated from mucus of the coral F. granulosa, collected from the Gulf of Eilat, Red Sea.

\section{Acknowledgements}

This work was supported by the National Institute for Biotechnology in the Negev (NIBN), ISF grant no. 511/02 and support for D. Z. B. Y. from Vattat. We would like to thank N. Siboni and O. Barnea for their help in sample collection and technical support and the InterUniversity Institute in Eilat for use of their facilities.

\section{References}

Brown, B. E. \& Bythell, J. C. (2005). Perspectives on mucus secretion in reef corals. Mar Ecol Prog Ser 296, 291-309.

Caumette, P., Guyoneaud, R., Duran, R., Cravo-Laureau, C. \& Matheron, R. (2007). Rhodobium pfennigii sp. nov., a phototrophic purple non-sulfur bacterium with unusual bacteriochlorophyll $a$ antennae, isolated from a brackish microbial mat on Rangiroa atoll, French Polynesia. Int J Syst Evol Microbiol 57, 1250-1255.

Cho, J. C. \& Giovannoni, S. J. (2003). Fulvimarina pelagi gen. nov., sp. nov., a marine bacterium that forms a deep evolutionary lineage of descent in the order 'Rhizobiales'. Int J Syst Evol Microbiol 53, 18531859.
Coffroth, M. A. (1990). Mucous sheet formation on Poritid corals: an evaluation of coral mucus as a nutrient source on reefs. Mar Biol 105, 39-49.

Cooney, R. P., Pantos, O., Le Tissier, M. D. A., Barer, M. R., O'Donnell, A. G. \& Bythell, J. C. (2002). Characterisation of the bacterial consortium associated with black band disease in coral using molecular microbiological techniques. Environ Microbiol 4, 401413.

Denner, E. B. M., Smith, G. W., Busse, H.-J., Schumann, P., Narzt, T., Polson, S. W., Lubitz, W. \& Richardson, L. L. (2003). Aurantimonas coralicida gen. nov., sp. nov., the causative agent of white plague type II on Caribbean scleractinian corals. Int J Syst Evol Microbiol 53, 1115-1122.

Felsenstein, J. (1985). Confidence limits on phylogenies: an approach using the bootstrap. Evolution 39, 783-791.

Felske, A., Rheims, H., Wolterink, A., Stackebrandt, E. \& Akkermans, A. D. L. (1997). Ribosome analysis reveals prominent activity of an uncultured member of the class Actinobacteria in grassland soils. Microbiology 143, 2983-2989.

Frias-Lopez, J., Zerkle, A. L., Boneheyo, G. T. \& Fouke, B. W. (2002). Partitioning of bacterial communities between seawater and healthy, black band diseased, and dead coral surfaces. Appl Environ Microbiol 68, 2214-2228.

Garrity, G. M. \& Holt, J. G. (2001). The road map to the Manual. In Bergey's Manual of Systematic Bacteriology, 2nd edn, vol. 1, pp. 119166. Edited by D. R. Boone, R. W. Castenholz \& G. M. Garrity. New York: Springer.

Giovannoni, S. J. \& Rappé, M. S. (2000). Evolution, diversity, and molecular ecology of marine prokaryotes. In Microbial Ecology of the Oceans, pp. 47-84. Edited by D. L. Kirchman. New York: Wiley-Liss.

Hiraishi, A., Urata, K. \& Satoh, T. (1995). A new genus of marine budding phototrophic bacteria, Rhodobium gen. nov., which includes Rhodobium orientis sp. nov. and Rhodobium marinum comb. nov. Int $J$ Syst Bacteriol 45, 226-234.

Jannasch, H. W. \& Jones, G. E. (1960). Caulobacter in sea water. Limnol Oceanogr 5, 432-433.

Kumar, S., Tamura, K. \& Nei, M. (2004). MEGA3: Integrated software for Molecular Evolutionary Genetics Analysis and sequence alignment. Brief Bioinform 5, 150-163.

Meikle, P., Richards, G. N. \& Yellowlees, D. (1987). Structural determination of the oligosaccharide side-chains from a glycoprotein isolated from the mucus of the coral Acropora formosa. J Biol Chem 262, 16941-16947.

Mesbah, M., Premachandran, U. \& Whitman, W. B. (1989). Precise measurement of the $\mathrm{G}+\mathrm{C}$ content of deoxyribonucleic acid by high-performance liquid chromatography. Int J Syst Bacteriol 39, 159167.

Rohwer, F., Breitbart, M., Jara, J., Azam, F. \& Knowlton, N. (2001). Diversity of bacteria associated with the Caribbean coral Montastrea franksii. Coral Reefs 20, 85-91.

Saitou, N. \& Nei, M. (1987). The neighbor-joining method: a new method for reconstructing phylogenetic trees. Mol Biol Evol 4, 406-425.

Shiba, T., Shioi, Y., Takamiya, K. I., Sutton, D. C. \& Wilkinson, C. R. (1991). Distribution and physiology of aerobic bacteria containing bacteriochlorophyll $a$ on the east and west coasts of Australia. Appl Environ Microbiol 57, 295-300.

Srinivas, T. N. R., Anil Kumar, P., Sasikala, Ch., Ramana, Ch. V. \& Imhoff, J. F. (2007). Rhodobium gokarnense sp. nov., a novel phototrophic alphaproteobacterium from a saltern. Int J Syst Evol Microbiol 57, 932-935. 
Suzuki, T., Muroga, Y., Takahama, M. \& Nishimura, Y. (2000). Roseibium denhamense gen. nov., sp. nov. and Roseibium hamelinense sp. nov., aerobic bacteriochlorophyll-containing bacteria isolated from the east and west coasts of Australia. Int J Syst Evol Microbiol 50, 2151-2156.

Wilson, K. (1987). Preparation of genomic DNA from bacteria. In Current Protocols in Molecular Biology, pp. 2.4.1-2.4.5. Edited by F. M. Ausubel, R. Brent, R. E. Kingston, D. D. Moore, J. G. Seidman,
J. A. Smith \& K. Struhl. New York: Green Publishing \& WileyInterscience.

Zaritsky, A. \& Woldringh, C. L. (2003). Localizing cell division in spherical Escherichia coli by nucleoid occlusion. FEMS Microbiol Lett 226, 209-214.

Zaritsky, A., Woldringh, C. L., Fishov, I., Vischer, N. O. E. \& Einav, M. (1999). Varying division planes of secondary constrictions in spheroidal Escherichia coli cells. Microbiology 145, 1015-1022. 